\title{
Paradigmas da leveza em tempos de modernidade
}

DOI: $10.1590 / 1809-58442017313$

\section{Enrickson Varsori}

(Universidade do Minho, Centro de Estudos de Comunicação e Sociedade, Programa de PósGraduação em Ciências da Comunicação. Braga, Portugal)

LIPOVETSKY, Gilles. Da leveza: Para uma civilização do ligeiro. Lisboa, Portugal: Edições 70, 2016. 350p.

De la Légèreté é o título original da obra publicada em 2015 na França por Gilles Lipovetsky, filósofo e sociólogo francês, membro do Conseil d'Analyse de la Société, órgão consultivo do primeiro-ministro francês e autor de vasta obra sobre as transformações da sociedade contemporânea, como “A Felicidade Paradoxal” (2010), "Ensaio sobre a Sociedade do Hiperconsumo” (2006), “A Cultura-Mundo” (2010) e “O Ecrã Global” (2010), estes dois últimos com Jean Serroy (2010), além de outras obras como “Os Tempos Hipermodernos” (2011) com Sébastien Charles.

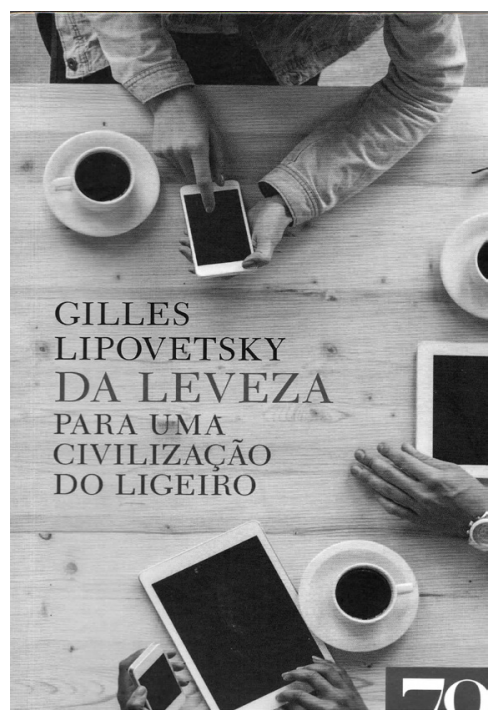

Em uma primeira instância, a nova obra de Lipovetsky trata da atual sociedade que vive de uma civilização que nos transporta para uma era da leveza. O culto pela magreza triunfa com mecanismos que primam o leve, que vão ao encontro dos hábitos mais comuns da sociedade e invadem as tecnologias, que estão cada vez mais micro e com ideais de serem mais estéticas, passando pelos paradigmas do desejo, do corpo etéreo e das promessas de que o leve é sinônimo do futuro. Para elucidar as ideias tratadas no título, o autor separa a obra em oito capítulos distintos, tendo como principal objetivo explanar de forma crítica o atual cenário sociocultural de uma sociedade que se vê presa em arquétipos cada vez mais ligeiros, do combate do leve contra o pesado.

O primeiro capítulo, Aligeirar a vida: bem-estar, economia e consumo, fragmenta os processos na linha histórica que aborda o combate moderno do leve contra o pesado, compreendidos entre os séculos XVIII e XX, com exemplificações do aligeiramento social com base nas políticas socioculturais e do bem estar que são impulsionadas pela revolução da alta tecnológica eletrônica e digital, marca do atual momento social que passamos, de uma vida que evidencia o prazer espontâneo que pode ser comprado e consumido. Ainda 
assim, fica o paradoxo sobre as necessidades do indivíduo em viver de forma leve e sobre o fardo de suas escolhas perante experiências que são cada vez mais pontuais. É possível também elucidar ao longo do capítulo construções e alusões anteriores feitas no livro "A cultura-mundo: Resposta a uma sociedade desorientada”, por Lipovetsky e Serroy (2014).

Em Um novo corpo, segundo capítulo, foca-se a questão da extensão da duração média da vida com as expressões do projeto moderno do que Lipovetsky chama de aligeiramento da vida, uma expressão do olhar particular das estéticas em matéria de magreza e juventude que criam regras para um corpo cada vez mais ideal.

O terceiro capítulo, O micro, o nano e o imaterial, elucida as grandes transformações a nível material desde o início das sociedades industriais. Lipovetsky relembra o facto de que o que demonstrava "confiança” vinha da solidez material, de infraestruturas pesadas (estradas, vias férreas, obras de arte), na qual foram trocadas pelo culto ao leve, do cada vez menos; menos peso, menos volume, menos massa, menos matéria. Era marcada pela micro e nanotecnologia, do imaterial como ferramentas em nuvem, do bigdata que desmaterializa no digital.

Moda e feminilidade, quarto capítulo, trabalha de forma crítica as questões relacionadas às subjetividades advindas da moda e do corpo humano. Em aspectos modernos, ganha notoriedade a performance do corpo como elemento da tirania das aparências, que ora nos liga na busca de sermos indivíduos únicos e ora nos liga na performance dos nossos próprios atributos físicos.

Ao passar para o quinto capítulo, Da leveza na arte à leveza da arte, Lipovetsky traça diversas relações entre a história da arte à busca universal e trans-histórica da leveza estética, consagrada por períodos de movimentos artísticos que primam por uma sociedade que é atualizada pela constante relação do humano com o novo, que é fruto de um consumo inconstante, ciosos por novidades.

Em Arquitetura e design: uma nova estética da leveza, sexto capítulo, o autor francês explana a atual arquitetura, de objetos miniaturizados e nómadas, nano-objetos, produtos light e outros tantos domínios do contemporâneo que, sob diversas formas, traduzem o avanço da revolução da leveza.

Seguindo para o sétimo capítulo, Será que somos cool?, centra-se o discurso do projeto moderno de aligeiramento da vida, uma forma de melhorar as condições de escolhas de como viver em sociedade. Partindo dessa análise, o autor explora os discursos atuais de uma sociedade que exalta uma vida à margem do que é considerado prazeroso e rejeita as limitações ao desejo devido às convenções sociais.

Ao chegar ao último capítulo, Liberdade, igualdade e leveza, Lipovetsky aborda de forma crítica o que ele denomina como "sociedade light", fruto de um capitalismo de sedução, no qual atinge contradições nos modos de agir fluídos e ao mesmo tempo que ainda são segurados pela gravidade das escolhas dentro da sociedade. O autor não poupa 
suas referências ao conectar os pensamentos críticos e conceitos como "barbárie” de Adorno (1995), “insignificância” de Castoriadis (1997), “pós-pensamento” de Sartori (2001), à alienação das massas de Debord (1997 [1967]), entre outras referências que compilam o atual momento crítico da sociedade da leveza.

Ao terminar o livro, em forma de ensaio, o autor ainda sublinha os benefícios, os fracassos, os efeitos perversos e nocivos da leveza-mundo que acompanham as diversas modificações estruturais na sociedade que é cada vez mais voltada para o atual, do presente e do efémero.

Ao finalizar a leitura de "Da leveza”, fica o convite do autor sobre o repensar da sociedade hipermoderna e conectada, fruto de diversas contradições que beiram o duo entre o leve e o pesado, dos discursos que invadem as áreas das ciências sociais e dos modos operantes de uma sociedade rápida, que não tem tempo para repensar e dialogar sobre os processos imediatos. A leveza que dialoga contra o próprio peso em nossas vidas, do sufrágio de utopias de desejo por norma causam angústias no próprio humano que, ao serem confrontados com o pensar, ignoram o debate, que em tempos modernos é a saída para uma vida mais saudável.

\section{Referências}

ADORNO, T. W. A filosofia e os professores. Rio de Janeiro: Paz e Terra, 1995.

CASTORIADIS, C. El avance de la insignificancia. Buenos Aires: Eudeba, 1997.

DEBORD, G. A sociedade do espetáculo. Rio de Janeiro: Contraponto, 1997 [1967].

LIPOVETSKY, G; SERROY, J. A Cultura Mundo: Resposta a uma sociedade desorientada. Lisboa: Edições 70, 2014.

SARTORI, Giovanni; VIDENS, Homo. Televisão e pós-pensamento. São Paulo: Edusc, 2001.

\section{Enrickson Varsori}

Jornalista, Bacharel em Comunicação Social pela Universidade Estadual de Londrina, Mestre em Comunicação Multimídia pela Universidade de Aveiro e Doutorando em Ciências da Comunicação pela Universidade do Minho, no Centro de Estudos de Comunicação e Sociedade. Programa de PósGraduação em Ciências da Comunicação. Braga, Portugal. E-mail: enrickson.varsori@gmail.com. 